\title{
Targeted plant improvement through genome editing: from laboratory to field
}

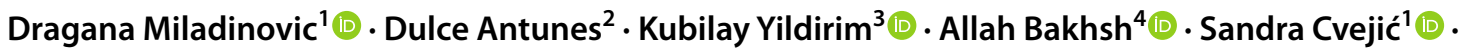

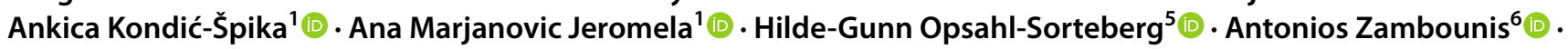 \\ Zoe Hilioti $^{7}$ (1)
}

Received: 29 June 2020 / Accepted: 20 December 2020 / Published online: 21 January 2021

(c) The Author(s) 2021

\begin{abstract}
Key message This review illustrates how far we have come since the emergence of GE technologies and how they could be applied to obtain superior and sustainable crop production.

Abstract The main challenges of today's agriculture are maintaining and raising productivity, reducing its negative impact on the environment, and adapting to climate change. Efficient plant breeding can generate elite varieties that will rapidly replace obsolete ones and address ongoing challenges in an efficient and sustainable manner. Site-specific genome editing in plants is a rapidly evolving field with tangible results. The technology is equipped with a powerful toolbox of molecular scissors to cut DNA at a pre-determined site with different efficiencies for designing an approach that best suits the objectives of each plant breeding strategy. Genome editing (GE) not only revolutionizes plant biology, but provides the means to solve challenges related to plant architecture, food security, nutrient content, adaptation to the environment, resistance to diseases and production of plant-based materials. This review illustrates how far we have come since the emergence of these technologies and how these technologies could be applied to obtain superior, safe and sustainable crop production. Synergies of genome editing with other technological platforms that are gaining significance in plants lead to an exciting new, post-genomic era for plant research and production. In previous months, we have seen what global changes might arise from one new virus, reminding us of what drastic effects such events could have on food production. This demonstrates how important science, technology, and tools are to meet the current time and the future. Plant GE can make a real difference to future sustainable food production to the benefit of both mankind and our environment.
\end{abstract}

Keywords Genome editing $\cdot$ Breeding $\cdot$ Plants $\cdot$ Improvement $\cdot$ Traits $\cdot$ Disease resistance

\section{Introduction}

Conventional breeding has enabled breeders to produce improved varieties of many crops and has led to increased food security and crops with higher yield and tolerance to

Communicated by Sang-Gyu Kim.

Zoe Hilioti

zhilioti@certh.gr

Institute of Field and Vegetable Crops, Novi Sad, Serbia

2 MED, FCT, Universidade do Algarve, Faro, Portugal

3 Department of Molecular Biology and Genetics, Faculty of Sciences, Ondokuzmayıs University, Samsun, Turkey

4 Department of Agricultural Genetic Engineering, Faculty of Agricultural Sciences and Technologies, Nigde Omer Halisdemir University, Nigde, Turkey
5 Faculty of Biosciences, Norwegian University of Life Sciences, Ås, Norway

6 Department of Deciduous Fruit Trees, Institute of Plant Breeding and Genetic Resources, ELGO-DEMETER, Naoussa, Greece

7 Institute of Applied Biosciences, CERTH, Thessaloniki, Greece 
biotic and abiotic stress, as well as increased nutrient content. However, in the era of the changing climate and greater consumer demands, breeders are still facing increasing challenges expected to be overcome. Projected changes in climate are expected to have far-reaching impacts on agricultural production, affecting future food production. The rising temperatures, droughts or floods in a certain geographical area, as well as new pests and diseases, will stress plants and demand new varieties and changed production systems differently in different geographic regions. Current global food systems are based on a few cereal crops and elite varieties feeding both animals and humans. Although seemingly efficient, it is not resilient to sudden changes in yield shocks posed by environmental changes or changed trading due to changed demands or changed financial market balance. By 2050, the FAO estimates that the food demand will have increased over $60 \%$ and it will have needed $50 \%$ more energy and $40 \%$ more water to feed the 10 billion people on the planet Earth. Furthermore, climate changes could result in a global temperature rise with detrimental effects which might be associated with disease outbreaks threatening the crop production and compromising the quality of the harvested products (Raza et al. 2019).

Genome editing provides new tools for the rational design of crops with improved traits (Fig. 1). These tools could enable faster production of new crop varieties, better adapted to any changes, whether environments or different consumer preferences around the world, and their transfer "from laboratory to field". Transgene-free genome editing (GE) technologies have opened a new era in plant precision breeding by providing better tools to increase (agro) biodiversity resources by means of trait engineering. In this review, we stress different aspects and potential applications of genome editing for plant improvement through precision breeding.

\section{Genome editing toolbox}

Genome editing involves the ability to introduce specific changes in DNA, such as the insertion, deletion or replacement of DNA through sequence-targeted recombination that has increased the speed, ease, and reproducibility of making local DNA changes. Although GE technologies have progressed rapidly and have successfully been applied to a wide range of cells and organisms, there is a considerable variation in their efficiency of cleavage at the target site. This variation could be explained by different modes of action of these technologies, as well as their differences in target site specificity, modular assembly and construction methods. In spite of variation in their efficiency, these technologies open up new opportunities for efficient plant improvement and some of the resulting changes, whether made through conventional breeding, gene transfer, genome editing or natural spontaneous mutation, cannot be distinguished.

The in vitro replication of specific DNA sequences by polymerase chain reaction (PCR) and the studies on the mechanisms of DNA double-strand breaks (DSBs) repair have allowed plant scientists to develop tools for targeted mutagenesis in plants. One of the first tools in the GE toolbox was the zinc finger nucleases (ZFNs). ZFNs are chimeric proteins with a DNA cleavage domain of FokI restriction endonuclease (a bacterial protein) and an array of three or four zinc fingers that were originally identified in sequence-specific eukaryotic transcription factors. The first eukaryotic sequence-specific transcription factor to be characterized was found to have zinc-binding repeats in its DNAbinding domain (Miller et al. 1985). Each zinc finger module recognizes three to four bases of sequence. These targeted hybrid restriction enzymes were developed by Srinivasan
Fig. 1 Concept of how plant genome editing can advance breeding targets

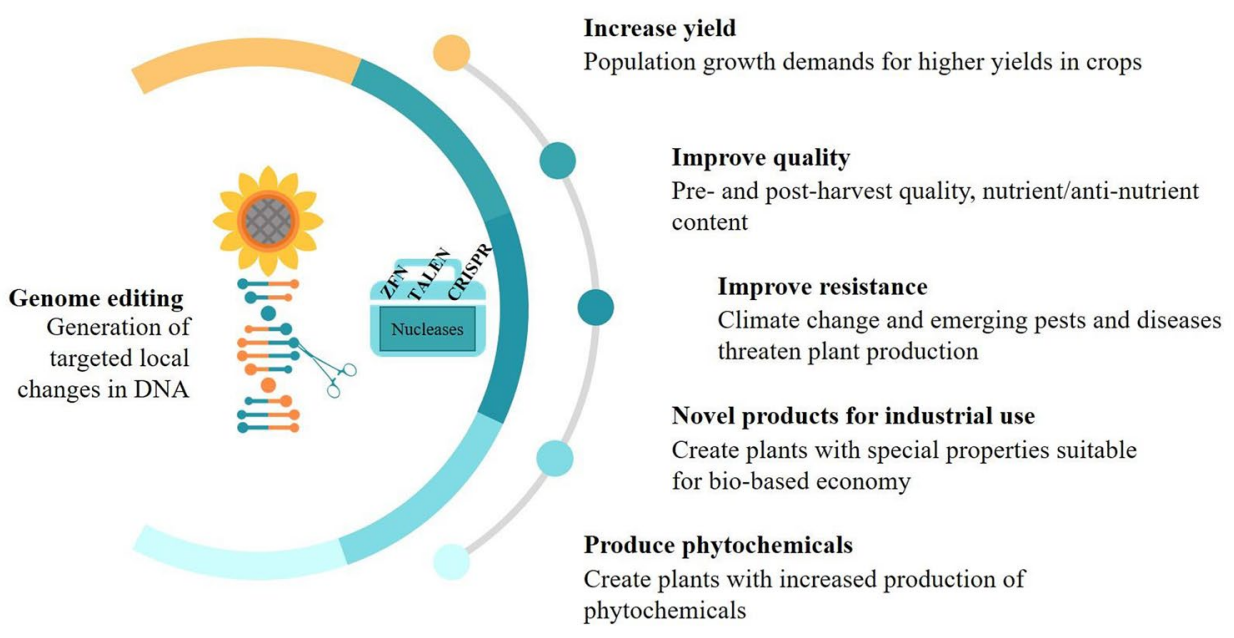

Concept of how plant genome editing can advance breeding targets 
Chandrasegaran and his team (Kim et al. 1996) and require dimerization mediated by the FokI cleavage domain for their function (Smith et al. 2000). A ZFN pair recognizes two adjacent DNA sequences on opposite strands with combined 18-nucleotide recognition specificity. In 2005, Dana Carroll and his team successfully achieved targeted mutagenesis in Arabidopsis by using ZFNs (Lloyd et al. 2005).

The second tool to edit genes, the transcription activatorlike effector nucleases (TALENs), is composed of Transcription Activator-Like Effectors (TALEs) and the FokI endonuclease. TALE proteins are expressed by plant bacterial pathogens to manipulate host gene transcription and promote successful infection. Like ZFNs, TALENs function as pairs in a similar way to create a break at a specific DNA sequence recognized by the TALE domain. TALENs for DNA recognition use a tandem array of 16 (or more) nearly identical protein modules, each of which targets one nucleotide at the DNA target site, making thus TALENs highly specific (Boch et al. 2009; Christian et al. 2010).

Meganucleases or homing endonucleases are sequencespecific endonucleases recognizing for cleavage long sequences (typically $18-30$ base pairs) that occur only once in any given genome and for this reason are rare-cutting enzymes. They generate DSBs, and the site-specific I-SceI is the prototypical meganuclease that has been used as a tool for genome engineering. For genome editing purposes, thousands of meganucleases have been redesigned and mutants created with new specificities (reviewed in Daboussi et al. 2015).

CRISPR/Cas (clustered regularly interspaced short palindromic repeats/CRISPR-associated protein) is an easier and more efficient genome editing tool than the engineered ZFNs and TALENs. It is based on the adaptive immune system in bacteria and archaea, enabling organisms to respond and eliminate invading viruses and plasmids (Jinek et al. 2012; Cong et al. 2013). This system consists of three components: the Cas9 nuclease from Streptococcus pyogenes (or similar alternatives), crRNA, and tracrRNA. The combination of the crRNA and tracrRNA into a single synthetic single guide RNA (sgRNA) has resulted in a simplified two-component reagent that is now widely used to introduce targeted double-stranded breaks in genomic DNA. The sgRNA contains approximately 20-base-long sequence complementary to the target DNA, which guides Cas9 to the right genomic location.

All above-described methods offer, with varying degrees of success, easy-to-design and cost-effective tools for precise and efficient plant genome editing. In recent years, they have also emerged as powerful tools that could be used for targeted plant improvement through directed mutagenesis and creation of varieties with increased stress resilience and enhanced quality convenient for different uses (Table 1).
Yield improvement through genome editing

Crop yield and consequently food production are highly influenced by complex interactions among climatic and soil conditions, abiotic and biotic stresses, and crop management practices. These interactions may have either negative or positive impact on plant growth and productivity (Jovičić et al. 2019; Kondić-Špika et al. 2019; Marjanović Jeromela et al. 2019). Therefore, the combined effect of different abiotic stresses (Song et al. 2014; Paul et al. 2019), as well as biotic and abiotic stresses (Pautasso et al. 2012; Pandey et al. 2015) on plant physiology and development, has extensively been investigated. Because biotic stresses have a huge role in potential yield loss and contribute to $15 \%$ of global declines in food production (Oerke 2005), studies with disease forecasting models for different regional climatic scenarios have been performed (Oldenburg et al. 2009; Caffarraa et al. 2012; Jevtić et al. 2017). With all this knowledge in mind, different strategies for crop production increase have been developed so far. A significant improvement of yield and other important traits was achieved by using conventional breeding tools for more than 50 years (Hristov et al. 2009; Mladenov et al. 2011). However, tackling climate change will largely depend on the new breeding techniques which possess the ability to develop desired traits more precisely and quickly than conventional breeding methods. CRISPR/ Cas9-based genome editing is one of these techniques, and it has been adopted in many crop species so far (Ricroch et al. 2017). In many studies, it was demonstrated that CRISPR/ Cas9 is an efficient technology for improving crop yield by knocking out the genes that negatively regulate yield-related traits (Zhang et al. 2018a; Lu et al. 2018; Liu et al. 2017b, a; Li et al. 2016a). A multiplexing GE strategy has been employed for trait pyramiding, and the following results have been obtained: enhanced grain size and weight in rice (Xu et al. 2016), early heading in rice (Li et al. 2017a), as well as increased kernel weight in wheat (Zhang et al. 2016). In a recent study, Huang et al. (2018) identified 57 genes controlling yield-related traits in 30 varieties of the Green Revolution phenotype known as "miracle rice" by combining genome sequencing and CRISPR/Cas9 technique and created knockout mutants of those 57 genes. Phenotyping of these mutants enabled identification of several genes that are crucial for regulating yield-related traits in rice. This new approach can be very useful in examining complex quantitative traits, including yield.

Genome editing has also been utilized to increase crop stress tolerance and to modify some important development and metabolic processes (Pandey et al. 2015; RodriguezLeal et al. 2017; Razzaq 2019a, b; Xu et al. 2019). These alterations in horticultural plants and crops were used as 
Table 1 Genome editing in plants for targeted improvement of different traits

\begin{tabular}{|c|c|c|c|c|}
\hline Trait & Plant/crop & GE tool used & Description & Reference \\
\hline \multirow[t]{5}{*}{ Yield } & Maize & CRISPR/Cas9 & Drought tolerance & Shi et al. (2017) \\
\hline & Rice & CRISPR/Cas9 & Identification of high-yield genes & Li et al. (2016a), Huang et al. (2018) \\
\hline & & CRISPR/Cas9 & Early maturation & Li et al. (2017a) \\
\hline & & CRISPR/Cas9 & Grain weight & Xu et al. (2016) \\
\hline & Tomato & ZFN & Phenotypic variability & Hilioti al. (2016) \\
\hline \multirow[t]{5}{*}{ Disease resistance } & Banana & CRISPR/Cas9 & Resistance against banana streak virus & Tripathi et al. (2019) \\
\hline & Cacao & CRISPR/Cas9 & Resistance against Phytophthora tropicalis & Fister et al. (2018) \\
\hline & Tomato & CRISPR/Cas9 & Resistance against powdery mildew & Nerkasov et al. (2017) \\
\hline & & CRISPR/Cas9 & Broad spectrum disease resistance & Thomazella et al. (2016) \\
\hline & Wheat & CRISPR/Cas9 & Resistance against powdery mildew & Zhang et al. (2017b) \\
\hline \multirow[t]{13}{*}{ Quality-food } & Peanuts & LANGUAGES & Increased oleic acid content & Wen et al. (2018) \\
\hline & Potato & LANGUAGES & Reduced levels of acrylamide & Clasen et al. (2016) \\
\hline & Rapeseed & CRISPR/Cas9 & Increased oleic acid content & Okuzaki et al. (2018) \\
\hline & Rice & CRISPR/Cas9 & High amylose content & Sun et al. (2017), Zhang et al. (2018b) \\
\hline & & ZFN & Low starch content & Jung et al. (2018) \\
\hline & Soybean & LANGUAGES & Altered fatty acids levels & Haun et al. (2014 ), Demorest et al. (2016) \\
\hline & Tomato & CRISPR/Cas9 & Increased lycopene content & Li et al. (2018a) \\
\hline & & CRISPR/Cas9 & Fruit ripening & Ito et al. (2015) \\
\hline & & CRISPR/Cas9 & Increase of y-aminobutyric acid & Li et al. (2018c) \\
\hline & & CRISPR/Cas9 & Parthenocarpic plants & Nonaka et al. (2017) \\
\hline & & CRISPR/Cas9 & Long shelf life & Ueta et al. (2017) \\
\hline & & ZFN & $\begin{array}{l}\text { Increased antioxidant content, low oxalic } \\
\text { acid (anti-nutrient), high fructose to } \\
\text { glucose ratio }\end{array}$ & Yu et al. (2017), Gago et al. (2017) \\
\hline & Wheat & CRISPR/Cas9 & Low gluten content & Sanchez-Leon et al. (2018) \\
\hline \multirow[t]{3}{*}{ Quality-feed } & Alfalfa & LANGUAGES & Reduced lignin content & USDA (2017) \\
\hline & Maize & Meganuclease & Increased level of starch in leaves and & USDA (2015) \\
\hline & Sorghum & CRISPR/Cas9 & Increased protein digestibility and quality & Li et al. (2018b) \\
\hline \multirow[t]{7}{*}{ Non-food } & Camelina & CRISPR/Cas9 & Altered fatty acids composition & $\begin{array}{l}\text { Aznar-Moreno and Durrett (2017), Ozseyhan } \\
\text { et al. (2018) }\end{array}$ \\
\hline & Cotton & CRISPR/Cas9 & $\begin{array}{l}\text { Lignocellulosic fibre formation and elonga- } \\
\text { tion }\end{array}$ & Zhu et al. (2018), Li et al. (2017b) \\
\hline & Miscanthus & CRISPR/Cas9 & Lignin reduction and content manipulation & Golfier et al. (2019) \\
\hline & Poplar & CRISPR/Cas9 & Lignin reduction and content manipulation & $\begin{array}{l}\text { Zhou et al, (2015), Wan et al. 2017 ; Wang } \\
\text { et al. (2017), Xu et al. (2017), Yang et al. } \\
\text { (2017) }\end{array}$ \\
\hline & Rice & CRISPR/Cas9 & Change in lignin composition & Takeda et al. (2018) \\
\hline & Sugarcane & $\begin{array}{l}\text { LANGUAGES } \\
\text { LANGUAGES }\end{array}$ & $\begin{array}{l}\text { Lignin reduction Increased saccharification } \\
\text { efficiency }\end{array}$ & Jung and Altpeter (2016), Kannan et al. 2018) \\
\hline & Switchgrass & CRISPR/Cas9 & Lignin reduction & Park et al. (2017) \\
\hline
\end{tabular}

indirect ways to improve their performance and yield in different environments.

\section{GE for improved disease resistance}

Plants are plagued by numerous phytopathogens, including fungi, bacteria, and viruses which cause severe crop yield losses worldwide (Dangl et al. 2013; Fisher et al. 2012).
Upon pathogen challenge in plants a signal transduction system is induced orchestrating the establishment of defence responses. The plant innate immunity has a fine-tuned twotiered immune perception system that initially involves the activation of pattern recognition receptors (PRRs), which perceive pathogen-associated molecular patterns (PAMPs) to initiate a basal defence response called pathogen-triggered immunity (PTI) (Thomma et al. 2011). In addition, intracellular nucleotide-binding site (NBS) and leucine-rich repeat 
(LRR)-containing cytoplasmic receptors (NLRs) initiate the effector-triggered immunity (ETI). The ETI system activates complex plant immune reactions for defence against pathogens (Win et al. 2012; Zhang et al. 2017a).

Plant defence mechanisms are constantly evolving to early respond against new diseases (Whitham et al. 2016; Zambounis et al. 2016). However, adaptation of pathogens to altering environment conditions happens quite faster than in plants. Innovative GE techniques including CRISPR-associated protein 9 (CRISPR/Cas9) system, TALENs and ZFNs, the first developed GE tool, as well as LAGLIDADG homing endonucleases have already been employed for engineering disease resistance in crops (Borrelli et al. 2018; Langner et al. 2018; Dong et al. 2019; Mushtaq et al. 2019). These GE techniques can enable precise and efficient development of plant varieties resistant to a broad-spectrum of pathogens, by modification of the genes that confer susceptibility to a given pathogen.

In general, the CRISPR/Cas9 system has high efficiency and simplicity, although there is the risk of off-target effects, allowing the development of plant species with enhanced disease resistance (Mushtaq et al. 2019). Identifying pathogen-resistance genes and gene target sites for CRISPR/Cas9based editing will enable functional testing of large numbers of variants. This approach has most frequently been used on the mildew resistance locus $\mathrm{O}(M L O)$, using RNA-guided Cas9 endonuclease (Nekrasov et al. 2017). CRISPR/Cas9 has also been used in rice for the induction of mutagenesis in the promoter of host-susceptibility $(S)$ OsSWEET family of putative sugar transporter genes, OSSWEETI4 and OSSWEET11, conferring tolerance against bacterial blight (Jiang et al. 2013). Recently, Thomazella et al. (2016) have reported that employment of CRISPR/Cas9 system enhanced disease resistance in tomato plants against different pathogens by inducing mutation in downy mildew resistance 6 (SIDMR61) gene. In grape, a Botrytis cinerea-responsive WRKY52 transcription factor has been targeted by the CRISPR/Cas9 system and the transgenic plants showed biallelic mutations less sensitive than the monoallelic mutants (Wang et al. 2018). In tree crops, the employment of transient leaf transformation targeting the non-expressor of pathogenesisrelated 3 (NPR3) gene, which is a suppressor of the immune system in Theobroma cacao, has led to improved resistance to Phytophthora tropicalis (Fister et al. 2018).

The application of CRISPR/Cas9 technology for disease resistance is among the most applicable GE approaches in agricultural research (Borrelli et al. 2018). The current scientific knowledge of the molecular mechanisms underlying numerous plant-microbe interactions has contributed in choosing candidate genes to be edited through GE approaches. Targeting a single gene whose inactivation might lead to disease resistance can be technically less challenging (Borrelli et al. 2018). Broad-spectrum disease resistance has been achieved by targeting mainly specific $S$ genes in many crops (Das and Rao 2015). These genes have emerged as the best candidates for engineering disease resistance, as they are often conserved among plant species and have the potential to be more durable in the field (Huibers et al. 2013).

The current knowledge of molecular mechanisms regulating plant-pathogen interactions would undoubtedly facilitate the employment of GE technologies in crop plants by the repression and activation of genes related to disease resistance. In order to increase the efficiency of GE approaches and avoid unexpected off-target mutations, rigorous design of the editing tool has to be performed (Borrelli et al. 2018). Main concerns for targeting and deploying GE approaches for broad-spectrum and durable resistance are the following: (i) There must be fundamental scientific knowledge about which gene(s) to modify and which type of modification to perform in these genes. For example, discovery of novel plant immune receptors and major virulence factors would enrich the repertoire and the pool of candidate deployable genes for GE. Comparative genomics approaches such as resistance gene enrichment sequencing (RenSeq) can also be employed to rapidly identify genomic variants in defencerelated genes that are linked to disease phenotypes (Jupe et al. 2014). (ii) Field tests are necessary for the evaluation of agronomic fitness, the durability of the disease resistances and the agronomic management of the edited crops (Borrelli et al. 2018). Particularly, durability could be achieved by targeting several resistance genes, multiple metabolic and immune pathways induced downstream of NLRs whose resistance would be more difficult to break down rapidly. This multiplexing approach becomes more challenging with increasing plant host ploidy levels, as, for example, in hexaploid wheat (A, B, and D genomes), where three $M L O$ gene alleles would need to be modified at once (Borrelli et al. 2018).

\section{Genome editing for improved food quality}

The nutrient content of plants can have significant impact on nutritional status and human health. Food quality of plantderived products is a combined outcome of the macronutrients, micronutrients, and phytochemicals, freedom from anti-nutrients and non-essential minerals or phytochemicals; and organoleptic attributes such as taste, flavour, aroma, appearance, texture, storage, and stability. Therefore, the concept of food quality embraces differentiated products for different end-uses. GE approaches allow targeted modifications, which, for example, in oilseed crops may be to create novel oil types by modifying their fatty acid profile or to improve the nutritional profiles or storage of fruit and vegetables. One of the first CRISPR'd crops that is expected 
to hit the market is waxy corn, a variety with edited deletion of the endogenous waxy gene $W x l$, which encodes the endosperm's granule-bound starch synthase responsible for making amylose, that resulted in elevated content of amylopectin and reduced levels of amylose (Waltz 2018). Corn starch with increased amylopectin content can have positive effects on the quality of frozen and canned food, by improving freeze-thaw properties in frozen food and making canned food creamier.

In plants, common nutritional targets include the modification of fatty acid composition and the enhancement of the antioxidant nutritional quality such as carotenoids, particularly lycopene, and flavonoids as well as the reduction of anti-nutrients. In tomato, a detailed characterization of eight ZFN-based mutant lines of LEAFY COTYLEDON1LIKE4 (LIL4) transcription factor generated through a transient expression of ZFNs in seeds revealed increased soluble solids content, which is of prime importance in tomato fruit and a breeding target affecting flavour and nutritional value. Mutant lines enriched in $\beta$-carotene and antioxidants, ascorbic acid or succinic acid, were produced. Notably, the reduced content of the anti-nutrient oxalic acid in several mutant fruits suggests that $L 1 L 4$ gene regulates the accumulation of this compound in tomato during fruit development (Gago et al. 2017). A CRISPR/Cas9 system in tomato targeted genes in carotenoid metabolic pathway and achieved a 5.1-fold increase in the lycopene content in tomato fruit ( $\mathrm{Li}$ et al. 2018a). In addition, tomatoes with increased $\gamma$-aminobutyric acid (GABA) levels have been produced by targeting two glutamate decarboxylase $(G A D)$ genes, GAD2 and GAD3, encoding a key enzyme in GABA biosynthesis. In this case, the CRISPR/Cas9 system created plants that produced tomatoes with 1.5- to tenfold higher GABA content, an amino acid that enhances the blood pressure-lowering function of tomato fruit (Nonaka et al. 2017). Generation of potato (Solanum tuberosum) varieties with undetectable levels of reducing sugars and reduced levels of acrylamide (a carcinogen) in processed chips was achieved though transient expression of TALENs designed to target the vacuolar acid invertase gene (Vlnv) (Clasen et al. 2016). In another work on potato, the granule-bound starch synthase gene, GBSS, that catalyses one of the enzymatic steps of starch synthesis, was mutated via CRISPR/Cas9. The mutated lines showed decreased levels of amylose and increased the amylopectin/amylose ratio (Andersson et al. 2017). In sorghum (Sorghum bicolor) grains, storage proteins called kafirins form protein bodies with poor digestibility. Kafirins are mostly composed of $\alpha$-kafirins and encoded by the $k l C$ family of highly similar genes. Li et al. (2018b) produced mutants with reduced kafirin levels and improved quality and digestibility of proteins using GE approach to target the $k 1 C$ genes.
Rice (Oryza sativa) is the staple food for over half of the world's population and nutritional improvements of this species may have great impact on the human population. Utilization of ZFNs in this crop induced mutations in starch synthase IVa gene (SSIVa) that encodes a soluble starch synthase involved in starch biosynthesis pathway. Generation of transgenic plants revealed low starch contents and dwarf phenotypes (Jung et al. 2018). Furthermore, CRISPR/ Cas 9 system was used to introduce a loss-of-function mutation into the Waxy gene in two widely cultivated elite japonica varieties, resulting in a reduced amylose content and converted the rice into glutinous ones (Sun et al. 2017; Zhang et al. 2018b). Other important cereal, wheat, contains gluten proteins that are not tolerated by individuals with celiac disease. A CRISPR/Cas9 system targeted a conserved region adjacent to the coding sequence for the 33 -mer in the $\alpha$-gliadin genes and produced plants with low gluten levels in seed kernels (Sánchez-León et al. 2018). Similarly, it was reported that the zein proteins have been reduced by $12.5 \%$ in kernels by disrupting a maize $M A D S$ gene (GRMZM2G059102) that activates zein gene promoters (Qi et al. 2016).

Soybean (Glycine max) oil is used in applications ranging from cooking and frying to industrial products. Change of individual fatty acids content in soybean oil could contribute to its increased shelf-life and frying stability, as well as improvement of its nutritional value. Soybean varieties with high oleic acid were created using TALEN technology to target the genes coding fatty acid desaturase 2 enzyme, FAD2$1 A$ and $F A D 2-1 B$. The oil profile of the mutant seeds meets the soybean industry's demand as the oleic acid increased fourfold (from 20 to $80 \%$ ), while linoleic acid decreased from 50 to less than 4\% (Haun et al. 2014). Working on the same breeding target, another TALEN-mediated approach was used to introduce combined mutations within two fatty acid desaturase genes $F A D 2-1 A, F A D 2-1 B$, and one fatty acid desaturase 3 gene, $F A D 3 A$, in order to stack quality traits in soybean. The resulting mutant lines had oleic acid levels above $80 \%$ and linoleic and linolenic acid levels below $3 \%$ compared to wild-type oil (Demorest et al. 2016). Okuzaki et al. (2018) used CRISPR/Cas9 system to modify $F A D 2$ gene, which encodes an enzyme that catalyses the desaturation of oleic acid, in Brassica napus cv. Westar. The mutated lines had increased content of oleic acid in seeds, compared to the wild-type. In peanut (Arachis hypogaea L.), mutant lines with a 0.5 -twofold increase in the oleic acid content were produced by targeted mutagenesis in the conserved coding sequence of $F A D 2$ gene by TALENs indicating that TALEN-mediated targeted mutagenesis can be used to increase the oleic acid content in edible peanut oil (Wen et al. 2018).

Plant cultivars with improved post-harvest quality are of significant importance for the reduction of food loss which 
is now estimated as $1 / 3$ of the total production. Food loss reduction will contribute to improved sustainability of food production as it will also reduce the use of production inputs and land use. In tomato, the CRISPR/Cas9 system was used to target the indoleacetic acid-induced protein 9 (IAA9) gene, which controls parthenocarpy, the production of seedless fruit without prior fertilization (Ueta et al. 2017). In the same species, ZFN-mediated mutagenesis of seeds by transient electroporation-based transformation with over 65\% efficiency targeted the LIL4 gene, a master transcription factor encoding the $\beta$-subunit of the trimeric complex NF-Y. LIL4 mutant lines had interesting agronomic traits such as earliness in flowering, variation in fruit size, colour, and shape (Hilioti et al. 2016). CRISPR/Cas9-mediated mutagenesis of the tomato (Solanum lycopersicum) RIPENING-INHIBITOR $(R I N)$ gene, which encodes a MADS-box transcription factor regulating fruit ripening led to RIN-protein defective mutants with incomplete-ripening of fruits and reduced red colour pigmentation compared to wild-type fruit (Ito et al. 2015). In tomato, the CRISPR/Cas9 system delivered by the Agrobacterium tumefaciens-mediated ALC (alcobaca) gene mutagenesis in the presence of the homologous repair template. The resulting mutants produced tomatoes with prolonged shelf life (Yu et al. 2017). The long shelf life is a critical trait for the quality of fresh fruit, and it is one of the main objectives in breeding programs as it influences fruit storage and shelf life. Tomato has mostly been studied as a classic climacteric model species with fleshy fruits and the molecular basis of fruit ripening and softening has been studied extensively. The RIN and COLORLESS NONRIPENING $(C N R)$ genes encode transcription factors involved in fruit ripening, and affect ripening in many fruit species, either climacteric or non-climacteric (Matas et al. 2009). Nevertheless, it has been shown that although it can improve shelf life, incomplete fruit ripening has adverse effects on organoleptic characteristics and nutritional quality. Thus, the challenge for ripening control is to modify the levels of gene expression sufficiently to extend shelf life without compromising the quality and sensory attributes (Matas et al. 2009).

\section{Alteration of lignocellulosic biomass by genome editing for improved feed quality}

Highly condensed coverage of lignified tissue on cell wall polysaccharides in forage crops physically separates digestive hydrolytic enzymes of ruminants from carbohydrate source of lignocellulosic biomass. Consequently, lignification limits digestibility of animals, decreases energy yields, and increases overall cost of animal feeding. Therefore, several bioengineering and GE studies have been carried out on forage plants (maize, sorghum, rice, and alfalfa) to reduce lignin with a concurrent increase in cellulose content (Nair and Lee 2015; Barros et al. 2018; Zhenga et al. 2018). CRISPR/Cas9-based mutagenesis has successfully been applied to several forage crops for stable mutations in genes related to lignin biosynthesis. Takeda et al. (2018) compared CRISPR and RNAi techniques on rice mutants that harbour frameshift mutations in the p-coumaroyl ester 3'-hydroxylase $\left(C 3^{\prime} H\right)$ gene, which is involved in both chlorogenic acid and lignin biosynthesis. In contrast to the RNAi-derived $C 3^{\prime} H$-knockdown mutants, the CRISPR-derived knockouts were severely dwarfed and sterile. The results of the study clearly indicated the impacts of $C 3^{\prime} H$ suppression on lignin composition and on the assembly of other cell wall components in rice. Such structural alterations in rice were reported to be highly useful for enhancements in biomass digestibility and saccharification. The same research group investigated the suppression effect of coniferaldehyde 5-hydroxylase (OsCAld5H1) gene, which modulates syringyl (S)/guaiacyl $(\mathrm{G})$ lignin composition ratio, on lignin structure of rice. Loss-of-function mutants clearly demonstrated alteration of S/G subunit in lignin composition of rice cell wall (Takeda et al. 2019). Miyamoto et al. (2019) used CRISPR technology to generate lignin-enriched transgenic rice via targeted mutagenesis of the transcriptional repressor OsMYB108. In another study, $C A D 2$ double mutants, deficient in cinnamyl alcohol dehydrogenase $(C A D)$, which encodes a key enzyme in lignin biosynthesis, were successfully created in rice with the same GE technique. Cell wall analysis of the $C A D 2$ mutants demonstrated altered lignification in rice and synergistic increase in saccharification efficiency via loss of function mutation (Matsumoto 2018). Pectin methyltransferase-deficient mutant rice was also generated by using CRSPR-mediated loss of function on acyltransferase 3 (OsAT3) and acyltransferase 4 (OsAT4). The result of both mutants indicated the effect of gene suppressions on pectin methyltransferase activity by a significant reduction in conversion of monolignols into corresponding lignin conjugates. CRISPR efficiency was also tested and successfully optimized for other forage crops such as maize (Svitashev et al. 2016; Armarego-Marriott 2020), grass (Liu et al. 2018) alfalfa (Gao et al. 2018; Curtin 2018 ), sorghum (Liu et al. 2019), wheat (Kumar et al. 2019), and soybean (Liu et al. 2019). In switchgrass, Park et al. (2017) targeted a key enzyme (4CL) in monolignol biosynthesis with CRISPR technology and produced plants with thinner cell walls. Remarkably, these plants had reduced lignin content by $30 \%$ and increased glucose and xylose release by $11 \%$ and $32 \%$ compared to wild type, respectively. 


\section{Targeted plant improvement for non-food uses}

Cellulose and hemicellulose are the main sources of sugar in the cell wall and the most valuable part of lignocellulosic biomass for the production of fuels, industrial chemicals and materials (Qian 2014). However, utilization of this sugar source in lignocellulosic materials has several restrictions due to protective coverage of lignin on them, which permits limited surface area for enzymatic and chemical hydrolysis (Ge et al. 2018). The manipulation of lignin composition and reduction of its content in plant cell wall improved suitability of lignocellulosic biomass for pulp, paper and textile industries as well as biofuel and easily digestible forage production (Häggman et al. 2013; Verma and Dwivedi 2014; Capstaff and Miller 2018). Various genetic and molecular techniques have been applied on lignocellulosic biomass to reduce lignin content and change its composition by downregulating/knocking-out the lignin biosynthetic genes and regulatory transcription factors.

Until recently, alteration of lignocellulosic biomass for several plant species has mostly been carried out by bioengineering technologies such as T-DNA gene insertionmutation, expression of antisense RNA, sense expression, co-suppression, and interference RNA (RNAi) (Zhao and Dixon 2014; Wang et al. 2015; Yang et al. 2019). However, such types of gene silencing methods have the risk of concomitant silencing of closely related gene family members that cause misinterpretations of the results and camouflaging the actual effects of individual gene silencing (Morgens et al. 2016). Widely used RNAi technology usually does not fully eliminate gene products (protein/enzyme), but only knockdown its expression. This unstable down-regulation is another important limitation of these gene silencing technique (Boettcher and McManus 2015; Zhou et al. 2015; Takeda et al. 2018). Another important shortcoming of these technologies is their dependency to stable gene transfer on the plant genome and creation of transgenic plants (Voelker et al. 2010; Van Acker et al. 2014; Zhou et al. 2015; Chutyser et al. 2018). All these problems can now easily be overcome by the use of new genome engineering methods for targeted genetic manipulation, such as ZNF, TALEN, and CRISPR (Häggman et al. 2013; Verma and Dwivedi 2014). Especially CRISPR system has become the most popular gene editing tool for several plant species, due to its low cost, simplicity and rapidness. CRISPR technology has made stable knockouts possible for specific target genes without insertion of foreign genetic material transfer into plant genome (Liu et al. 2017a). Therefore, it is possible to alter original base pair arrangement within plant genome without making it transgenic (Clifton-Brown et al. 2019). These bio-editing methods have started to be utilized for editing lignin biosynthetic genes to create mutant plants with reduced lignin content and better lignocellulosic properties (Gao 2018; Chanoca et al. 2019).

Carbohydrate polymers found in lignocellulosic biomass are used in pulp and paper industry. Due to the association of cellulose microfibrils with the condensed coverage of lignin, chemical delignification of wood is essential to remove lignin and produce high-quality paper with better brightness and whiteness (Chutyser et al. 2018). Chemical delignification requires expensive chemicals harmful for polysaccharide components of wood and for the environment due to toxic pollutants (Wang et al. 2018). To avoid these problems, GE could effectively be used to reduce lignin content and alter its composition in woody plants to improve quality of pulping, increase wood extractability, and reduce mill effluents (Verma and Dwivedi 2014). CRISPR-based gene knockout and silencing approach was effectively utilized to strongly down-regulate genes functional in lignin biosynthetic pathway in poplar species. The first stably CRISPR-based genome-edited poplar with high efficiency was reported by Fan et al. (2015). Bioinformatics tools to simplify GE were then developed quickly for heterozygous poplar species (Xue and Tsai 2015; Xue et al, 2015). Lignin biosynthesis via phenylpropanoid metabolism and cell wall traits are the main targets for the GE studies in poplar. CRISPR-Cas9 mutational efficiency was tested on lignin and flavonoid biosynthesis in the woody perennial $P$. tremula $\times$ alba by disrupting three 4-coumarate:CoA ligase genes (4CL1, 4CL2 and 4CL5) (Zhou et al. 2015). Based on the results, $4 C L 1$ and $4 C L 2$ play a primary role in lignin and flavonoid biosynthesis. Mutations in $4 C L 1$ gene revealed a reduction in lignification, whereas $4 C L 2$ gene proved to be involved in chlorogenic acid production in leaves. In the same poplar study, CRISPR/Cas9-mediated mutagenesis in $4 C L$ gene revealed a $20 \%$ reduction in lignin content and a $30 \%$ decrease in S/G ratio. Importantly, each independent $4 C L 1$ line developed uniform reddish-brown wood, a phenotype associated with lignin deficiency. In previous RNAi-based studies, $4 C L 1$ suppression created patchy wood discoloration due to the unstable nature of RNAi-mediated gene silencing method (Voelker et al. 2010; Van Acker et al. 2014). CRISPR-based knockout studies targeting the MYB transcription factors in poplar were also studied to reduce lignin content. These studies revealed a negative regulatory role of some MYBs on the phenylpropanoid metabolism and secondary cell wall biosynthesis (PtoMYB156, PtoMYB115 and PtoMYB170), while some others increased proanthocyanidin biosynthesis (PtoMYB156and PtoMYB57), lignification (PtoMYB156 and PtoMYB170), and flavonoid accumulation (PtrMYB57 and PtoMYB115) (Wan et al. 2017; Wang et al. 2017; Xu et al. 2017; Yang et al. 2017). In poplar, brassinosteroid biosynthetic PtoDWF4 gene knockout plants generated by CRISPR significantly decreased 
biomass production indicating the important role of the gene in secondary cell wall synthesis and wood formation (Shen et al. 2018). CRISPR-based knockouts for BRANCHED 1 (BRC1-1) and BRANCHED 2 (BRC1-2) transcription factors, which are important centres of signals controlling the ability of a bud to grow out, revealed altered shoot architecture and increased bud outgrowth (Muhr et al. 2018). Recent studies also reported successful CRISPR/Cas9 mutational efficiency for poplar flowering genes and a large mutation dataset (Elorriaga et al. 2018; Bruegmann et al. 2019). These studies demonstrated promising strategies for the production of lignocellulosic biomass using less land and helping the conservation of natural forests and reducing the environmental problem of pulp and paper processing.

Solar energy stored in plants is extensively used as fossil fuel in last century for energy production, which results in of greenhouse gases emission and consequently global warming. Interestingly, the same solar energy stored in plant biomass can be used as renewable, eco-friendly, sustainable, and better alternative to fossil fuels (Verma and Dwivedi 2014; Capstaff and Miller 2018). The energy found in lignocellulosic biomass can be effectively released by its biological conversion into biofuels (alcohols) using microorganisms and/or enzymes (Zeng et al. 2014). This idea was realized firstly on food crops such as corn, sugarcane and wheat which led to increase in price of food grains and other related products. This food/fuel competition entailed the usage of lignocellulosic biomass as alternative feedstocks for biofuel production. Plants grown on marginal agricultural lands such as switchgrass, miscanthus, sorghum, and poplar as well as straw producing grain crops (maize, soybean, rice, wheat, yucca, and barley) are the main sources of lignocellulosic biomass that can be utilized for the production of biofuels (Yoo et al. 2018; Wang et al. 2012). Unfortunately, crystalline recalcitrance nature of lignocellulose, heterogeneity degree of polymerization, rough particle size and protective covering of lignin create an extra expensive pre-treatment process to loosen lignin and allow polysaccharide accessibility for enzymatic saccharification and microbial fermentation (Welker et al. 2015). Therefore, it is necessary to generate easily degradable lignocellulose producer plants to decrease the requirement for pre-treatment methods. These unsuitable characteristics of lignocellulosic biomass for biofuel production were targeted in several genetic manipulation studies to obtain plants more amenable to bioprocessing. Genome editing techniques were effectively utilized to create lignin double mutants in biomass crops. TALEN, for instance, was successfully applied in sugarcane, a crop accounting for nearly $80 \%$ of sugar produced worldwide and the most important source of ethanol production. Jung and Altpeter (2016) successfully applied a TALEN-based approach to target the conserved region of caffeic acid O-methyltransferase (COMT) and to create multi-allelic mutagenesis in lignin biosynthesis and generate lines exhibiting a $29-32 \%$ reduction in lignin content compared to controls with significantly reduced $\mathrm{S}$ subunit content and elevated hemicellulose content. In another study, these TALEN-mediated COMT mutants were grown on field to test their survival and biomass production performance. The results of the study revealed $20 \%$ reduction in lignin content and S/G ratio, which resulted in $44 \%$ improved saccharification efficiency. Biomass production performance of COMT mutants did not differ significantly from the original cultivar under field conditions (Kannan et al. 2018). As mentioned earlier, Park et al. (2017) mutated a key gene (4CL) in lignin biosynthesis with CRSPR/Cas system in switchgrass, a model biomass species characterized by high ploidy level. The results of the study revealed less lignin content and significantly increased glucose and xylose release in knockout plants compared to control. Furthermore, another CRISPR/ Cas9 system introduced simultaneous mutations at three gene loci, teosinte branched $l(t b l) a, b$ and phosphoglycerate mutase $(P G M)$, when stably transformed mesophyll protoplasts of switchgrass showing that the CRISPR/Cas9 can be used for multiplex GE and produce homozygous mutant plants in $\mathrm{T} 0$ generation. Interestingly, plants with $t b l$ gene mutations had increased tiller numbers, which is a useful genetic material for breeding switchgrass cultivars with high biomass yield (Liu et al. 2018). Miscanthus (Miscanthus spp.) is a non-food, second-generation bioenergy crop and a perennial C4 grass that grows well even in marginal lands. The biomass of Miscanthus has a carbohydrate content of more than $60 \%(\mathrm{w} / \mathrm{w})$ regardless of the variety, in which approximately $40 \%$ is cellulose based on dry weight (Qin et al. 2012). Glucose generated from the hydrolysis of cellulose is the main fermentable sugar for bioethanol production and thus the cellulose content of Miscanthus is a major agronomic characteristic in using this grass as an energy crop. The transcription factors MsSCM1 and MsMYB103, which were found to act as regulators of lignin biosynthesis leading to specific lignin qualities, represent interesting targets for lignin content manipulation and composition towards tailored biomass (Golfier et al. 2019). GE approaches are not documented yet for this species. CRISPR-derived $\mathrm{C}^{\prime}{ }^{\prime} \mathrm{H}-$ knockdown in rice indicated suppression on lignin composition, and on the assembly of other cell wall components in rice (Takeda et al. 2018). Such structural alterations in rice cell walls reportedly enhanced biomass digestibility and saccharification. Recently, hydroxycinnamoyl transferase in Arabidopsis was targeted by fibre-specific promoter based Cas9 (Liang et al. 2019). This study revealed that xylemspecific Cas9 expression is able to reduce lignification in xylem cells by avoiding defects on pleiotropic growth of full knockout Arabidopsis mutants.

The increasing demand for biofuel production leads to an increased demand for the raw plant material, and it has 
been a driving force for plant researchers to create plant feedstocks tailored for biodiesel production using either classical or modern breeding tools for the creation of oilseed varieties with higher oil content and optimal fatty acid composition for biodiesel production. Biodiesel is a fuel composed of mono-alkyl esters of long-chain fatty acids derived from biomass from plant oils, which consists mostly (>95\%) of triacylglycerols (TAGs) and short-chain alcohols. Another source of biodiesel that reduces its cost is waste vegetable oils and non-edible crude vegetable oils. Currently, non-edible oil yielding plants for the second-generation biodiesel production include Jatropha, castor bean, cotton, Pongamia, tobacco, mahua, neem, and Camelina. Plant oils derived mainly from TAGs in seed tissues (embryo or endosperm) represent a promising source of renewable biofuel. For most of these feedstocks, agronomic and crop production improvements are just beginning to be applied through GE approaches. Oilseed rape (Brassica napus) is an annual crop native to the Mediterranean region and Asia that produces seeds with an oil content of about $40-45 \%$. The CRISPR/Cas9 system was used to target FAD2 gene, which encodes an enzyme that catalyses the desaturation of oleic acid, creating mutants with statistically significant increase in the oleic acid content compared to that present in wild-type seeds (Okuzuki et al. 2018). Jatropha (Jatropha curcas) is another promising plant for biodiesel production due to its high oil content in seeds. Several studies suggested that exogenous cytokinin treatment can significantly increase the total number of flowers per inflorescence, the female-tomale flower ratio, and the seed yield (Fröschle et al. 2017; Pan and Xu 2011). The CRISPR/Cas9 system was used to study the function of cytokinin metabolic gene CYP735A gene and found that the concentrations of trans-zeatin (tZ) and tZ-riboside decreased significantly in the gene mutants, which showed severely retarded growth (Cai et al. 2018). In camelina (Camelina sativa L.), an allohexaploid species of the Brassicaceae family and an oilseed crop for biofuel production, Cas9 and a sgRNA targeted all three diacylglycerol O-acyltransferase 1 (DGAT1) or phospholipid:diacylglycerol acyltransferase 1 (PDAT1) homeologs simultaneously, which are important genes for triacylglycerol biosynthesis. The resulting mutant lines reduced seed oil and altered fatty acid composition. This application demonstrated the ability of the technology to target all three homeologs simultaneously in this species (Aznar-Moreno and Durrett 2017). In another application of CRISPR/Cas9 technology in the same species, three alleles of the fatty acid elongase 1 gene were targeted aiming to reduce the amounts of very long-chain fatty acids (VLCFAs) and improve fatty acid composition in seeds. VLCFAs were reduced to less than $2 \%$ of the total fatty acids compared to over $22 \%$ present in the wild types (Ozseyhan et al. 2018).
Lignocellulosic biofibres have attracted a renewed attention in recent years due to their low production costs, decomposable nature, proper physical properties, and environmental friendliness. Biofibre producing plants such as herb, cotton, jute, and flax have important utilization potential in biomedical science, textile, and automotive industry. Although it improves mechanical strength of the biofibre, the presence of lignin in lignocellulosic biomass of these plants decreases elastic properties of fibres and utilization, especially in textile industry. Therefore, genetic manipulation on fibre plants to obtain low-lignin fibres with improved elastic properties is the most desirable target for bioengineers. Cotton plant is the most important biofibre producing species in that group due to the importance of its fibre and derivatives for our daily life and the world economy. Therefore, GE with CRISPR mutational efficiency on cotton has been tested and successfully established recently. These studies revealed a moderate to high gene editing efficiency for both exogenous transferred genes (Chen et al. 2017; Janga et al. 2017) and endogenous genes in cotton (Chen et al. 2017; Gao et al. 2017; Li et al. 2017b; Wang et al. 2017, 2018). Li et al. (2017b) developed a CRISPR/Cas9 system in cotton by targeting GhMYB25 genes functional in lignocellulosic fibre formation and elongation. A similar system was also applied in cotton to mutate alanine-rich protein (ALARP) gene, which encodes an alanine-rich protein that is preferentially expressed in cotton fibres (Zhu et al. 2018).

\section{Future perspectives: Can plants lead the way in Europe and beyond?}

Development of new breeding techniques, such as GE, could provide new perspectives for more efficient plant breeding. In crops, most of the agronomically important traits are complex phenotypic traits controlled by polygenes, and it is usually necessary to study more than a single gene or single class of genes to understand molecular mechanisms underlying respective traits. GE tools could be used by breeders to evaluate and validate the strength of the predictive breeding value of a given candidate gene by easily transferring its best alleles into different genetic backgrounds (Nogué et al. 2016). As different genes can be individually engineered at the same time, GE also provides the means for modification of linked genes or QTLs that are usually difficult to segregate due to the limitations of meiotic recombination (Flavell 2010).

As in genetic transformation, regeneration efficiency could be a bottleneck for the effective deployment of GE techniques in crop breeding (Miladinović et al. 2019). Many crops such as cotton and sunflower are either recalcitrant or have difficult and long transformation protocols (TaškiAjduković et al. 2010; Gao et al. 2017). Furthermore, since 
regeneration capacity is genotype-dependent, in crops where a transformation method has been established, such as sorghum, many of the elite varieties remain uncooperative, not being amenable to transformation (Botella 2019). In addition to the already-mentioned problems, in polyploid crops the GE protocols should enable simultaneous targeting of multiple alleles, which could be an obstacle for GE of wheat and other crops with complex genomes. Thus, it is crucial to determine the efficiency of the sgRNAs selected for the CRISPR/Cas9 system in advance, as the sequence of the target site has a strong influence on the efficiency of the sgRNA (Wang et al. 2014). Agroinfiltration is one of the methods that has been used for CRISPR/Cas9 target validation in hard-to-transform crops such as cotton (Gao et al. 2017). In tomato, DNA constructs for ZFNs were introduced by electroporation of seeds (Hilioti et al. 2016).

Another aspect that could potentially affect application and potential impact of GE, as well as its public acceptance, is the choice of agronomic or quality traits to be either improved or introduced. In most of the crops, the choice of the traits to be improved, either by classical breeding of genetic modifications, was mostly technology-driven, taking into account the needs and benefits to farmers, processors, and distributors. This especially stands for vegetables, which were constantly selected for improved "shelf life" and shipping quality that created varieties such as "cardboard" strawberry and bouncing tomato (Georges and Ray 2017). Combined with the misconception that all these flavourless varieties are produced through transgenic approaches, this leads to discrepancies in acceptance of the new varieties by farmers and industry on the one side, and final consumers on the other side. Hence, when choosing the crops and traits to be improved by GE, one has to bear in mind that the public will accept new technology only when individuals decide for themselves that products obtained with the use of new breeding tools will contribute to their personal well-being.

These further emphasize the importance of the need for keeping the public well informed, since, based on the past experiences when experts and consumers have disagreed, the opinions expressed by experts might not override consumer perspectives in any meaningful way (Lassoued et al. 2019). Hence, it is the responsibility of scientists to keep an adequate flow of information in a manner that would promote an informed public understanding of the goals and means of GE, while providing a clear account of risks vs. benefits, as well as emphasizing the risks of opportunities lost (Miladinović 2020). Such interaction with society may prevent the spread of misinformation.

Finally, although GE editing approach is superior and much more precise than classical genetic modifications, it will likely face similar challenges depending on how governments perceive the technology. So far, many countries have indicated that if no foreign DNA is present in a crop variety, it will not require any additional regulatory oversight or risk assessment, which is in contrast to the EU judgement that even in the absence of foreign DNA any genome-edited variety must be regulated as equivalent to transgenic GMO varieties (Lassoued et al. 2019). This will ultimately contribute to shaping the public perception of GE, but also affect its application and impact in the EU.

Overall, plant GE is a powerful tool in the development of novel plant species with desired agronomic traits and nutritional value. Developing GE elite plants carrying targeted gene mutation(s) without foreign DNA may help increase public acceptance of agricultural products and free them from regulatory monitoring in order to advance their use in plant breeding programs and commercial-scale production. Plant systems are relatively economical to maintain with short generation cycle and ease to be handled compared to animals, and hence, they can be particularly attractive for testing new concepts and develop new approaches in GErelated research that aims to improve accuracy, versatility, and efficiency of these molecular tools and apply them with ease to other systems. However, the lack of regulations and uncertainty about possible applications could affect implementation of GE for plant improvement. The researchers have knowledge and resources to apply these new tools for introduction of new traits into plants, but for the time being this research is generally put on hold, waiting for new regulations and proper assessments of GE methods used for plant improvement. Gene targeting in plants plays an important role in providing new information on genetic and genomic analyses, gene networks and single gene variant function, which in case of well-conserved genes across living species may advance our understanding on the cellular and molecular workings of advanced eukaryotic species and at the same time pave the way for development and implementation of new, more efficient breeding tools, and shorter time needed to transfer the knowledge from laboratory to field.

Acknowledgements The authors would like to thank Ms. Tanja Vunjak for the help with correction of English grammar and language of the manuscript.

Author contribution statement $\mathrm{ZH}$ and DM contributed substantially to the conception and the design of the review; MDA, KY, AB, AKS, AMJ, HGOS, AZ, ZH, and DM drafted the text; DM and ZH drafted the final version of the review; MDA, KY, AB, SC, AKS, AMJ, HGOS, $\mathrm{AZ}, \mathrm{ZH}$, and $\mathrm{DM}$ edited and approved the version to be published.

Funding The work of all authors on this manuscript was supported by the COST action CA18111 "Genome editing in plants-a technology with transformative potential". DM, SC, AKŠ, and AMJ were also supported by Ministry of Education, Science and Technological Development of the Republic of Serbia, grant number 451-0368/2020-14/200032. KY was supported by Turkish Scientific and Technological Research Council, project number TOVAG-217O232. 


\section{Compliance with ethical standards}

Conflict of interest The authors declare that they have no conflict of interest.

Open Access This article is licensed under a Creative Commons Attribution 4.0 International License, which permits use, sharing, adaptation, distribution and reproduction in any medium or format, as long as you give appropriate credit to the original author(s) and the source, provide a link to the Creative Commons licence, and indicate if changes were made. The images or other third party material in this article are included in the article's Creative Commons licence, unless indicated otherwise in a credit line to the material. If material is not included in the article's Creative Commons licence and your intended use is not permitted by statutory regulation or exceeds the permitted use, you will need to obtain permission directly from the copyright holder. To view a copy of this licence, visit http://creativecommons.org/licenses/by/4.0/.

\section{References}

Andersson M, Turesson H, Nicolia A, Fält AS, Samuelsson M, Hofvander P (2017) Efficient targeted multiallelic mutagenesis in tetraploid potato (Solanum tuberosum) by transient CRISPR-Cas9 expression in protoplasts. Plant Cell Rep 36:117-128. https:// doi.org/10.1007/s00299-016-2062-3

Armarego-Marriott T (2020) Stiffening stems: identification of the stiff1 gene involved in maize stalk strength. Plant Cell 32:12. https://doi.org/10.1105/tpc.19.00852

Aznar-Moreno JA, Durrett TP (2017) Simultaneous targeting of multiple gene homeologs to alter seed oil production in Camelina sativa. Plant Cell Physiol 58:1260-1267. https://doi.org/10.1093/ $\mathrm{pcp} / \mathrm{pcx} 058$

Barros J, Temple S, Dixon RA (2018) Development and commercialization of reduced lignin alfalfa. Curr Opin Biotechnol 56:48-54. https://doi.org/10.1016/j.copbio.2018.09.003

Boch J, Scholze H, Shornack S, Landgraf A, Hahn S, Kay S, Lahaye T, Nickstadt A, Bonas U (2009) Breaking the code of DNA binding specificity of TAL-type III effectors. Science 326:1509-1512. https://doi.org/10.1126/science.1178811

Boettcher M, McManus MT (2015) Choosing the right tool for the job: RNAi, TALEN, or CRISPR. Mol Cell 58:575-585. https ://doi.org/10.1016/j.molcel.2015.04.028

Borrelli VMG, Brambilla V, Rogowsky P, Marocco A, Lanubile A (2018) The enhancement of plant disease resistance using CRISPR/Cas9 technology. Front Plant Sci 9:1245. https://doi. org/10.3389/fpls.2018.01245

Botella JR (2019) Now for the hard ones: Is there a limit on CRISPR genome editing in crops? J Exp Bot 70:734-737. https://doi. org/10.1093/jxb/erz007

Bruegmann T, Deecke K, Fladung M (2019) Evaluating the efficiency of gRNAs in CRISPR/Cas9 mediated genome editing in poplars. Int J Mol Sci 20:3623. https://doi.org/10.3390/ijms2 0153623

Caffarraa A, Rinaldia M, Eccela E, Rossib V, Pertota I (2012) Modelling the impact of climate change on the interaction between grapevine and its pests and pathogens: European grapevine moth and powdery mildew. Agric Ecosyst Environ 148:89-101. https ://doi.org/10.1016/j.agee.2011.11.017

Cai L, Zhang L, Fu Q, Xu ZF (2018) Identification and expression analysis of cytokinin metabolic genes IPTs, CYP735A and CKXs in the biofuel plant Jatropha curcas. Peer J 6:4812. https://doi. org/10.7717/peerj.4812
Capstaff NM, Miller AJ (2018) Improving the yield and nutritional quality of forage crops. Front Plant Sci 9:535. https://doi. org/10.3389/fpls.2018.00535

Chanoca A, de Vries L, Boerjan W (2019) Lignin engineering in forest trees. Front Plant Sci 10:912. https://doi.org/10.3389/ fpls.2019.00912

Chen XG, Lu XK, Shu N, Wang S, Wang J, Wang D, Guo L, Yea W (2017) Targeted mutagenesis in cotton (Gossypium hirsutum L.) using the CRISPR/Cas9 system. Sci Rep 7:44304. https://doi. org/10.1038/srep44304

Christian M, Cermak T, Doyle EL, Schmidt C, Zhang F, Hummel A, Bogdanove AJ, Voytas DF (2010) Targeting DNA double-strand breaks with TAL effector nucleases. Genetics 186:757-761. https ://doi.org/10.1534/genetics.110.120717

Chutyser W, Renders T, Van Den Bosch S, Koelewijn S-F, Beckham GT, Sels BF (2018) Chemicals from lignin: an interplay of lignocellulose fractionation, depolymerisation, and upgrading. Chem Soc Rev 47:852-908. https://doi.org/10.1039/c7cs00566k

Clasen BM, Stoddard TJ, Luo S, Demorest Z, Li J, Cedrone F, Tibebu R, Davison S, Ray EE, Daulhac A, Coffman A, Yabandith A, Retterath A, Haun W, Baltes NJ, Mathis L, Voytas DF, Zhang $\mathrm{F}$ (2016) Improving cold storage and processing traits in potato through targeted gene knockout. Plant Biotechnol J 14:169-176. https://doi.org/10.1111/pbi.12370

Clifton-Brown J, Harfouche A, Casler MD, Dylan Jones H, Macalpine WJ, Murphy-Bokern D, Smart LB, Adler A, Ashman C, AwtyCarroll D, Bastien C, Bopper S, Botnari V, Brancourt-Hulmel M, Chen Z, Clark LV, Cosentino S, Dalton S, Davey C, Dolstra O, Donnison I, Flavell R, Greef J, Hanley S, Hastings A, Hertzberg M, Hsu T-W, Huang LS, Iurato A, Jensen E, Jin X, Jørgensen U, Kiesel A, Kim D-S, Liu J, McCalmont JP, McMahon BG, Mos M, Robson P, Sacks EJ, Sandu A, Scalici G, Schwarz K, Scordia D, Shafiei R, Shield I, Slavov G, Stanton BJ, Swaminathan K, Taylor G, Torres AF, Trindade LM, Tschaplinski T, Tuskan GA, Yamada T, Yu CY, Zalesny RS Jr, Zong J, Lewandowski I (2019) Breeding progress and preparedness for mass-scale deployment of perennial lignocellulosic biomass crops switchgrass, miscanthus, willow and poplar. Glob Change Biol Bioenergy 11:118-151. https://doi.org/10.1111/gcbb.12566

Cong L, Ran FA, Cox D, Lin S, Barretto R, Habib N, Hsu PD, Wu X, Jiang W, Marraffini L (2013) Multiplex genome engineering using CRISPR/Cas systems. Science 339:819-823. https://doi. org/10.1126/science. 1231143

Curtin SJ (2018) Editing the Medicago truncatula genome: targeted mutagenesis using the CRISPR-Cas9 reagent. Methods Mol Biol 1822:161-174. https://doi.org/10.1007/978-1-4939-8633-0_12

Daboussi F, Stoddard TJ, Zhang F (2015) Engineering meganuclease for precise plant genome modification. In: Zhang F, Puchta H, Thomson JG (eds) Advances in new technology for targeted modification of plant genomes. Springer, New York, pp 21-38

Dangl JL, Horvath DM, Staskawicz BJ (2013) Pivoting the plant immune system from dissection to deployment. Science 341:746-751. https://doi.org/10.1126/science.1236011

Das G, Rao GJN (2015) Molecular marker assisted gene stacking for biotic and abiotic stress resistance genes in an elite rice cultivar. Front Plant Sci 6:698. https://doi.org/10.3389/fpls.2015.00698

Demorest ZL, Coffman A, Baltes NJ, Stoddard TJ, Clasen BM, Luo S, Retterath A, Yabandith A, Gamo ME, Bissen J, Mathis L, Voytas DF, Zhang F (2016) Direct stacking of sequence-specific nuclease-induced mutations to produce high oleic and low linolenic soybean oil. BMC Plant Biol 16:225. https://doi.org/10.1186/ s12870-016-0906-1

Dong OX, Ronald PC (2019) Genetic engineering for disease resistance in plants: recent progress and future perspectives. Plant Physiol 180:26-38. https://doi.org/10.1104/pp.18.01224 
Elorriaga E, Klocko AL, Ma C, Strauss SH (2018) Variation in mutation spectra among CRISPR/Cas9 mutagenized poplars. Front Plant Sci 9:594. https://doi.org/10.3389/fpls.2018.00594

Fan D, Liu T, Li C, Jiao B, Li S, Hou Y, Luo K (2015) Efficient CRISPR/Cas9-mediated targeted mutagenesis in Populus in the first generation. Sci Rep 5:12217. https://doi.org/10.1038/srep1 2217

Fisher MC, Henk DA, Briggs CJ, Brownstein JS, Madoff LC, McCraw SL, Gurr SJ (2012) Emerging fungal threats to animal, plant and ecosystem health. Nature 484:186-194. https://doi.org/10.1038/ nature 10947

Fister AS, Landherr L, Maximova SN, Guiltinan MJ (2018) Transient expression of CRISPR/Cas9 machinery targeting TcNPR3 enhances defense response in Theobroma cacao. Front Plant Sci 9:268. https://doi.org/10.3389/fpls.2018.00268

Flavell R (2010) From genomics to crop breeding. Nat Biotechnol 28:144-145

Fröschle M, Horn H, Spring O (2017) Effects of the cytokinins 6-benzyladenine and forchlorfenuron on fruit-, seed- and yield parameters according to developmental stages of flowers of the biofuel plant Jatropha curcas L. (Euphorbiaceae). Plant Growth Regul 81:293-303. https://doi.org/10.1007/s10725-016-0206-7

Gago C, Drosou V, Paschalidis K, Guerreiro A, Miguel G, Dulce Antunes M, Hilioti M (2017) Targeted gene disruption coupled with metabolic screen approach to uncover the LEAFY COTYLEDON1-LIKE4 (L1L4) function in tomato fruit metabolism. Plant Cell Rep 36:1065-1082. https://doi.org/10.1007/s0029 9-017-2137-9

Gao C (2018) The future of CRISPR technologies in agriculture. Nat Rev Mol Cell Biol 19:275-276. https://doi.org/10.1038/ nrm.2018.2

Gao R, Feyissa BA, Croft M, Hannoufa A (2018) Gene editing by CRISPR/Cas9 in the obligatory outcrossing Medicago sativa. Planta 247:1043-1050. https://doi.org/10.1007/s0042 5-018-2866-1

Gao W, Long L, Tian XQ, Xu FC, Liu J, Singh PK, Botella JR, Song C (2017) Genome editing in cotton with the CRISPR/Cas9 system. Front Plant Sci 8:1364. https://doi.org/10.3389/fpls.2017.01364

Ge X, Chang C, Zhang L et al (2018) Conversion of lignocellulosic biomass into platform chemicals for biobased polyurethane application. In: Li Yebo, Ge Xumeng (eds) Advances in bioenergy. Elsevier, Amsterdam, pp 161-213

Georges F, Ray H (2017) Genome editing of crops: a renewed opportunity for food security. GM Crops Food 8:1-12. https://doi. org/10.1080/21645698.2016.1270489

Golfier P, Unda F, Murphy EK, Xie J, He F, Zhang W, Mansfield SD, Rausch T, Wolf S (2019) Distinct and overlapping functions of Miscanthus sinensis MYB transcription factors SCM1 and MYB103 in lignin biosynthesis. bioRxiv. https://doi. org/10.1101/629709

Haun W, Coffman A, Clasen BM, Demorest ZL, Lowy A, Ray E, Retterath A, Stoddard T, Juillerat A, Cedrone F, Mathis L, Voytas DF, Zhang F (2014) Improved soybean oil quality by targeted mutagenesis of the fatty acid desaturase 2 gene family. Plant Biotechnol J 12:934-940. https://doi.org/10.1111/pbi.12201

Hilioti Z, Ganopoulos I, Ajith S, Bossis I, Tsaftaris A (2016) A novel arrangement of zinc finger nuclease system for in vivo targeted genome engineering: the tomato LEC1-LIKE4 gene case. Plant Cell Rep 35:2241-2255. https://doi.org/10.1007/s0029 9-016-2031-x

Hristov N, Mladenov N, Đurić V, Kondić-Špika A, MarjanovićJeromela A (2009) Improvement of wheat quality in cultivars released in Serbia during the 20th century. Cereal Res Commun 38: 111-121. https://doi.org/10.1556/CRC.37.2009.4.9

Huang J, Li J, Zhou J, Wang L, Yang S, Hurst LD, Li WH, Tian D (2018) Identifying a large number of high-yield genes in rice by pedigree analysis, whole-genome sequencing, and CRISPRCas9 gene knockout. PNAS 115:E7559-E7567. https://doi. org/10.1073/pnas.1806110115

Huibers RP, Loonen AE, Gao D, Van den Ackerveken G, Visser RG, Bai Y (2013) Powdery mildew resistance in tomato by impairment of SIPMR4 and SIDMR1. PLoS ONE 8:e67467. https://doi. org/10.1371/journal.pone.0067467

Häggman H, Raybould A, Borem A, Fox T, Handley L, Hertzberg M, Lu MZ, Macdonald P, Oguchi T, Pasquali G, Pearson L, Peter G, Quemada H, Séguin A, Tattersall K, Ulian E, Walter C, McLean M (2013) Genetically engineered trees for plantation forests: key considerations for environmental risk assessment. Plant Biotechnol J 11:785-798. https://doi.org/10.1111/pbi.12100

Ito Y, Nishizawa-Yokoi A, Endo M, Mikami M, Toki S (2015) CRISPR/Cas9-mediated mutagenesis of the RIN locus that regulates tomato fruit ripening. Biochem Biophys Res 467:76-82. https://doi.org/10.1016/j.bbrc.2015.09.117

Janga MR, Campbell LM, Rathore KS (2017) CRISPR/Cas9-mediated targeted mutagenesis in upland cotton (Gossypium hirsutum L.). Plant Mol Biol 94:349-360. https://doi.org/10.1007/s1110 3-017-0599-3

Jeromela AM, Terzić S, Jankulovska M, Zorić M, Kondić-Špika A, Jocković M, Hristov N, Crnobarac J, Nagl N (2019) Dissection of year related climatic variables and their effect on winter rapeseed (Brassica napus L.) development and yield. Agronomy 9:517. https://doi.org/10.3390/agronomy9090517

Jevtić R, Župunski V, Lalošević M, Lj Ž (2017) Predicting potential winter wheat yield losses caused by multiple disease systems and climatic conditions. Crop Protect 99:17-25. https://doi. org/10.1016/j.cropro.2017.05.005

Jiang W, Zhou H, Bi H, Yang FM, B, Weeks DP, (2013) Demonstration of CRISPR/Cas9/sgRNA- mediated targeted gene modification in Arabidopsis, tobacco, sorghum and rice. Nucleic Acids Res 41:188. https://doi.org/10.1093/nar/gkt780

Jinek M, Chylinski K, Fonfara I, Hauer M, Doudna JA, Charpentier E (2012) A programmable dual-RNA-guided DNA endonuclease in adaptive bacterial immunity. Science 337:816-821. https://doi. org/10.1126/science.1225829

Jovicic D, Popovic MB, Marjanovic Jeromela A, Nikolic Z, Ignjatov M, Milosevic D (2019) The interaction between salinity stress and seed aging during germination of Brassica napus seeds. Seed Sci Technol 47: 47-52. https://doi.org/10.15258/sst.2019.47.1.05

Jung JH, Altpeter F (2016) TALEN mediated targeted mutagenesis of the caffeic acid $O$-methyltransferase in highly polyploid sugarcane improves cell wall composition for production of bioethanol. Plant Mol Biol 92:131. https://doi.org/10.1007/s1110 3-016-0499-y

Jung Y, Nogoy FM, Lee S, Cho Y, Kang K (2018) Application of ZFN for site directed mutagenesis of rice SSIVa gene. Biotechnol Bioproc Eng 23:108-115. https://doi.org/10.1007/s1225 7-017-0420-9

Jupe F, Chen X, Verweij W, Witek K, Jones JD, Hein I (2014) Genomic DNA library preparation for resistance gene enrichment and sequencing (RenSeq) in plants. Methods Mol Biol 1127:291303. https://doi.org/10.1007/978-1-62703-986-4_22

Kannan B, Jung JH, Moxley GW, Lee SM, Altpeter F (2018) TALENmediated targeted mutagenesis of more than 100 COMT copies/ alleles in highly polyploid sugarcane improves saccharification efficiency without compromising biomass yield. Plant Biotechnol J 16:856-866. https://doi.org/10.1111/pbi.12833

Kim YG, Cha J, Chandrasegaran S (1996) Hybrid restriction enzymes. Zinc finger fusions to FokI cleavage domain. PNAS 93:1156-1160

Kondić-Spika A, Mladenov N, Grahovac N, Zorić M, Mikić S, Trkulja D, Marjanović-Jeromela A, Miladinović D, Hristov N (2019) Biometric analyzes of yield, oil and protein contents of wheat 
(Triticum aestivum L.) genotypes in different environments. Agronomy 9: 270. https://doi.org/10.3390/agronomy9060270

Kumar R, Kaur A, Pandey A (2019) GP1CRISPR-based genome editing in wheat: a comprehensive review and future prospects. Mol Biol Rep 46:3557-3569. https://doi.org/10.1007/s11033-01904761-3

Langner T, Kamoun S, Belhaj K (2018) CRISPR Crops: plant genome editing toward disease resistance. Ann Rev Phytopathol. https:// doi.org/10.1146/annurev-phyto-080417-050158

Lassoued R, Macall DM, Hesseln H, Phillips PVB, Smyth SJ (2019) Benefits of genome-edited crops: expert opinion. Transgenic Res 28:247-256. https://doi.org/10.1007/s11248-019-00118-5

Li R, Fu D, Zhu B, Luo Y, Zhu H (2018) CRISPR/Cas9-mediated mutagenesis of lncRNA1459 alters tomato fruit ripening. Plant J 94:513-524. https://doi.org/10.1111/tpj.13872

Li S, Gao F, Xie K, Zeng X, Cao Y, Zeng J, He Z, Ren Y, Li W, Deng Q, Wang S, Zheng A, Zhu J, Liu H, Wang L, Li P (2016) The OsmiR396c-OsGRF4-OsGIF1 regulatory module determines grain size and yield in rice. Plant Biotechnol J 14:2134-2146. https://doi.org/10.1111/pbi.12569

Li A, Jia S, Yobi A, Ge Z, Sato S, Zhang C, Angelovici R, Clemente TE, Holding D (2018a) Editing of an alpha-kafirin gene family increases digestibility and protein quality in sorghum. Plant Physiol 177:1425-1438. https://doi.org/10.1104/pp.18.00200

Li M, Li X, Zhou Z, Wu P, Fang M, Pan X, Lin Q, Luo W, Wu G, Li $\mathrm{H}$ (2016) Reassessment of the four yield-related genes Gnla, $D E P 1, G S 3$, and IPA1 in rice using a CRISPR/Cas9 system. Front Plant Sci 7:377. https://doi.org/10.3389/fpls.2016.00377

Li C, Unver T, Zhang BH (2017) A high-efficiency CRISPR/Cas9 system for targeted mutagenesis in cotton (Gossypium hirsutum L.). Sci Rep 7:43902. https://doi.org/10.1038/srep43902

Li X, Wang Y, Chen S, Tian H, Fu D, Zhu B, Luo Y, Zhu H (2018) Lycopene is enriched in tomato fruit by CRISPR/Cas9-mediated multiplex genome editing. Front Plant Sci 9:559. https://doi. org/10.3389/fpls.2018.00559

Li X, Zhou W, Ren Y, Tian X, Lv T, Wang Z, Fang J, Chu C, Yang J, Bu Q (2017) High-efficiency breeding of early-maturing rice cultivars via CRISPR/Cas9-mediated genome editing. J Genet Genomics 44:175-178. https://doi.org/10.1016/j.jgg.2017.02.001

Liang Y, Eudes A, Yogiswara S, Jing B, Benites VT, Yamanaka R, Cheng-Yue C, Baidoo EE, Mortimer JC, Scheller HV, Loqué D (2019) A screening method to identify efficient sgRNAs in Arabidopsis, used in conjunction with cell-specific lignin reduction. Biotechnol Biofuels 12:130. https://doi.org/10.1186/s1306 8-019-1467-y

Liu J, Chen J, Zheng X, Wu F, Lin Q, Heng Y, Tian P, Cheng ZJ, Yu X, Zhou K, Zhang X, Guo X, Wang J, Wang H, Wan J (2017a) GW5 acts in the brassinosteroid signaling pathway to regulate grain width and weight in rice. Nat Plants 3:17043. https://doi. org/10.1038/nplants.2017.43

Liu X, Surui Wu, Jiao Xu, Sui C, Wei J (2017b) Application of CRISPR/Cas9 in plant biology. Acta Pharm Sinica B 7:292-302. https://doi.org/10.1016/j.apsb.2017.01.002

Liu G, Li J, Godwin ID (2019) Genome editing by CRISPR/Cas9 in sorghum through biolistic bombardment. Methods Mol Biol 1931:169-183. https://doi.org/10.1007/978-1-4939-9039-9_12

Liu Y, Merrick P, Zhang ZZ, Ji CH, Yang B, Fei SZ (2018) Targeted mutagenesis in tetraploid switchgrass (Panicum virgatum L.) using CRISPR/Cas9. Plant Biotechnol J 16:381-393. https:// doi.org/10.1111/pbi.12778

Lloyd A, Plaisier CL, Carroll D, Drews GN (2005) Targeted mutagenesis using zinc finger nucleases in Arabidopsis. PNAS 102:22322237. https://doi.org/10.1073/pnas.0409339102

Lu K, Wu B, Wang J, Zhu W, Nie H, Qian J, Huang W, Fang Z (2018) Blocking amino acid transporter OsAAP3 improves grain yield by promoting outgrowth buds and increasing tiller number in rice. Plant Biotechnol J 16:1710-1722. https://doi.org/10.1111/ pbi.12907

Matas AJ, Gapper N, Chung M, Giovannoni JJ, Rose JKC (2009) Biology and genetic engineering of fruit maturation for enhanced quality and shelf-life. Curr Opin Biotechnol 20:197-203. https ://doi.org/10.1016/j.copbio.2009.02.015

Matsumoto N (2018) Generation and characterization of rice CAD2 CAldMT1 double mutants with altered lignin content and structure. Sustaine Humanosphere 13:44-44

Miladinović D, Hladni N, Radanović A, Jocić S, Cvejić S (2019) Sunflower and climate change: possibilities of adaptation through breeding and genomic selection. In: Kole C (ed) Genomic designing of climate-smart oilseed crops. Springer International Publishing, Cham, pp 173-238

Miladinović D (2020) Communicating biotechnology and its impacts. iPLANTA COST Action CA15223 WG5 Meeting, pp. 6

Miller J, McLachlan AD, Klug A (1985) Repetitive zinc-binding domains in the protein transcription factor IIIA from Xenopus oocytes. EMBO J 4:1609-1614

Miyamoto T, Takada R, Tobimatsu Y, Takeda Y, Suzuki S, Yamamura M, Osakabe K, Osakabe Y, Sakamoto M, Umezawa T (2019) OsMYB108 loss-of-function enriches p-coumaroylated and tricin lignin units in rice cell walls. Plant J 98:975-987. https://doi. org/10.1111/tpj.14290

Mladenov N, Hristov N, Kondić-Špika A, Đurić V, Jevtić R, Mladenov $\mathrm{V}$ (2011) Breeding progress in grain yield of winter wheat cultivars grown at different nitrogen levels in semiarid conditions. Breed Sci 61:260-268. https://doi.org/10.1270/jsbbs.61.260

Morgens D, Deans R, Li A, Bassik MS (2016) Systematic comparison of CRISPR/Cas9 and RNAi screens for essential genes. Nat Biotechnol 34:634-636. https://doi.org/10.1038/nbt.3567

Muhr M, Paulat M, Awwanah M, Brinkkötter M, Teichmann T (2018) CRISPR/Cas9-mediated knockout of Populus BRANCHED1 and BRANCHED2 orthologs reveals a major function in bud outgrowth control. Tree Physiol 38:1588-1597. https://doi. org/10.1093/treephys/tpy088

Mushtaq M, Sakina A, Wani SH, Shikari AB, Tripathi P, Zaid A, Galla A, Abdelrahman M, Sharma M, Singh AK, Salgotra RK (2019) Harnessing genome editing techniques to engineer disease resistance in plants. Front Plant Sci 10:550. https://doi.org/10.3389/ fpls.2019.00550

Nair RB, Lee H (2015) Compositions for reduced lignin content in sorghum and improving cell wall digestibility, and methods of making the same. US Patent App 14/611,168

Nekrasov V, Wang C, Win J, Lanz C, Weigel D, Kamoun S (2017) Rapid generation of a transgene-free powdery mildew resistant tomato by genome deletion. Sci Rep 7:482. https://doi. org/10.1038/s41598-017-00578-x

Nogué F, Mara K, Collonnier C, Casacuberta JM (2016) Genome engineering and plant breeding: impact on trait discovery and development. Plant Cell Rep 35:1475-1486. https://doi.org/10.1007/ s00299-016-1993-z

Nonaka S, Arai C, Takayama M, Matsukura C, Ezura H (2017) Efficient increase of $\gamma$-aminobutyric acid (GABA) content in tomato fruits by targeted mutagenesis. Sci Rep 7:7057. https://doi. org/10.1038/s41598-019-55119-5

Oerke EC (2005) Crop losses to pests. J Agric Sci 144:31-43. https:// doi.org/10.1017/s0021859605005708

Okuzaki A, Ogawa T, Koizuka C, Kaneko K, Inaba M, Imamura J, Koizuka N (2018) CRISPR/Cas9-mediated genome editing of the fatty acid desaturase 2 gene in Brassica napus. Plant Physiol Biochem 131:63-69. https://doi.org/10.1016/j.plaphy.2018.04.025

Oldenburg E, Manderscheid R, Erbs M, Weigel HJ (2009) Interaction of free air carbon dioxide enrichment (FACE) and controlled summer drought on fungal infections of maize. In: Feldmann F, Alford DV, Furk C (eds) Crop plant resistance to biotic and 
abiotic factors: current potential and future demands. Julius Kühn-Institut, Berlin, pp 75-83

Ozseyhan ME, Kang J, Mu X, Lu C (2018) Mutagenesis of the FAE1 genes significantly changes fatty acid composition in seeds of Camelina sativa. Plant Physiol Biochem 123:1-7. https://doi. org/10.1016/j.plaphy.2017.11.021

Pan B-Z, Xu Z-F (2011) Benzyladenine treatment significantly increases the seed yield of the biofuel plant Jatropha curcas. J Plant Growth Regul 30:166-174. https://doi.org/10.1007/s0034 4-010-9179-3

Pandey P, Sinha R, Mysore KS, Senthil-Kumar M (2015) Impact of concurrent drought stress and pathogen infection on plants. In: Mahalingam R (ed) Combined stresses in plants. Springer International Publishing, Cham, pp 203-222

Park JJ, Yoo CG, Flanagan A, Pu Y, Debnath S, Ge Y, Ragauskas AJ, Wang ZY (2017) Defined tetra-allelic gene disruption of the 4-coumarate:coenzyme A ligase 1 (Pv4CL1) gene by CRISPR/Cas9 in switchgrass results in lignin reduction and improved sugar release. Biotechnol Biofuels 10:284. https://doi. org/10.1186/s13068-017-0972-0

Paul K, Sorrentino M Lucini L, Rouphael Y, Cardarelli M, Bonini P, Reynaud H, Canaguier R, Trtílek M, Panzarová K et al (2019) Understanding the biostimulant action of vegetal-derived protein hydrolysates by high-throughput plant phenotyping and metabolomics: A case study on tomato. Front Plant Sci 10:47

Pautasso M, Döring TF, Garbelotto M, Pellis L, Jeger MJ (2012) Impacts of climate change on plant diseases-opinions and trends. Eur J Plant Pathol 133:295-313. https://doi.org/10.1007/s1065 8-012-9936-1

Qi W, Zhu T, Tian Z, Li C, Zhang W, Song R (2016) High-efficiency CRISPR/Cas9 multiplex gene editing using the glycine tRNAprocessing system-based strategy in maize. BMC Biotechnol 16:58. https://doi.org/10.1186/s12896-016-0289-2

Qian EW (2014) Pretreatment and Saccharification of Lignocellulosic Biomass. In: Tojo S, Hirasawa T (eds) Research Approaches to Sustainable Biomass Systems. Academic Press, Cambridge, pp 181-204

Qin J, Yang Y, Jiang J, Yi Z, Xiao L, Miao Ai X, Chen Z (2012) Comparison of lignocellulose composition in four major species of Miscanthus. Afr J Biotechnol 11:12529-12537. https://doi. org/10.5897/AJB 11.3248

Raza A, Razzaq A, Mehmood SS, Zou X, Zhang X, Lv Y, Xu J (2019) Impact of climate change on crops adaptation and strategies to tackle its outcome: review. Plants (Basel) 8:34. https://doi. org/10.3390/plants8020034

Razzaq A, Sadia B, Raza A, Khalid Hameed M, Saleem F (2019) Metabolomics: a way forward for crop improvement. Metabolites 9:303. https://doi.org/10.3390/metabo9120303

Razzaq A, Saleem F, Kanwal M, Mustafa G, Yousaf S, Arshad HMI, Hameed MK, Khan MS, Joyia FA (2019) Modern trends in plant genome editing: an inclusive review of the CRISPR/Cas9 toolbox. Int J Mol Sci 20:4045. https://doi.org/10.3390/ijms201640 45

Ricroch A, Clairand P, Harwood W (2017) Use of CRISPR systems in plant genome editing: toward new opportunities in agriculture. Emerg Top Life Sci 1:169-182. https://doi.org/10.1042/etls2 0170085

Rodríguez-Leal D, Lemmon ZH, Man J, Bartlett ME, Lippman ZB (2017) Engineering quantitative trait variation for crop improvement by genome editing. Cell 171:470-480. https://doi. org/10.1016/j.cell.2017.08.030

Shen Y, Li Y, Xu D, Yang C, Li C, Luo K (2018) Molecular cloning and characterization of a brassinosteriod biosynthesis-related gene PtoDWF4 from Populus tomentosa. Tree Physiol 38:14241436. https://doi.org/10.1093/treephys/tpy027
Shi J, Gao H, Wang H, Lafitte HR, Archibald RL, Yang M, Hakimi SM, Mo H, Habben JE (2017) ARGOS8 variants generated by CRISPR-Cas9 improve maize grain yield under field drought stress conditions. Plant Biotechnol J 15:207-216. https://doi. org/10.1111/pbi.12603

Smith J, Bibikova M, Whitby FG, Reddy AR, Chandrasegaran S, Caroll D (2000) Requirements for double-strand cleavage by chimeric restriction enzymes with zinc finger DNA-recognition domains. Nucleic Acids Res 28:3361-3369. https://doi.org/10.1093/ $\operatorname{nar} / 28.17 .3361$

Song Y, Yu J, Huang B (2014) Elevated CO2-mitigation of high temperature stress associated with maintenance of positive carbon balance and carbohydrate accumulation in Kentucky bluegrass. PLOS 9:1-11

Sun YW, Jiao GA, Liu ZP, Zhang X, Li JY, Guo XP, Du WM, Du JL, Francis F, Zhao YD, Xia LQ (2017) Generation of high-amylose rice through CRISPR/Cas9-mediated targeted mutagenesis of starch branching enzymes. Front Plant Sci 8:298. https://doi. org/10.3389/fpls.2017.00298

Svitashev S, Schwartz C, Lenderts B, Young JK, Cigan AM (2016) Genome editing in maize directed by CRISPR-Cas9 ribonucleoprotein complexes. Nat Commun 7:13274. https://doi. org/10.1038/ncomms 13274

Sánchez-León S, Gil-Humanes J, Ozuna CV, Giménez MJ, Sousa C, Voytas DF, Barro F (2018) Low-gluten, nontransgenic wheat engineered with CRISPR / Cas9. Plant Biotechnol J 16: 902-910. https://doi.org/10.1111/pbi.12837

Takeda Y, Suzuki S, Tobimatsu Y, Osakabe K, Osakabe Y, Ragamustari SK, Sakamoto M, Umezawa T (2019) Lignin characterization of rice coniferaldehyde 5-hydroxylase loss-of-function mutants generated with the CRISPR/Cas9 system. Plant J 97:543-554. https://doi.org/10.1111/tpj.14141

Takeda Y, Tobimatsu Y, Karlen SD, Koshiba T, Suzuki S, Yamamura M, Murakami S, Mukai M, Hattori T, Osakabe K, Ralph J, Sakamoto M, Umezawa T (2018) Downregulation of p-coumaroyl ester 3-hydroxylase in rice leads to altered cell wall structures and improves biomass saccharification. Plant J 95:796-811. https ://doi.org/10.1111/tpj.13988

Taški-Ajduković K, Nagl N, Miladinović D (2010) Towards reducing genotype specificity in regeneration protocols after somatic hybridization between cultivated sunflowerand wild Helianthus species. Acta Biol Hung 61:214-223. https://doi.org/10.1556/ ABiol.61.2010.2.9

Thomazella DP, Brail Q, Dahlbeck D, Staskawicz B (2016) CRISPRCas9 mediated mutagenesis of a DMR6 ortholog in tomato confers broad-spectrum disease resistance. bioRxiv. https://doi. org/10.1101/064824

Thomma BP, Nurnberger T, Joosten MH (2011) Of PAMPs and effectors: the blurred PTI-ETI dichotomy. Plant Cell 23:4-15. https ://doi.org/10.1105/tpc.110.082602

Tripathi JN, Ntui VO, Ron M, Muiruri SK, Britt A, Tripathi L (2019) CRISPR/Cas9 editing of endogenous banana streak virus in the B genome of Musa spp. overcomes a major challenge in banana breeding. Commun Biol 2:46. https://doi.org/10.1038/s4200 3-019-0288-7

Ueta R, Abe C, Watanabe T, Sugano SS, Ishihara R, Ezura H, Osakabe Y, Osakabe K (2017) Rapid breeding of parthenocarpic tomato plants using CRISPR/Cas9. Sci Rep 7:507. https://doi. org/10.1038/s41598-017-00501-4

United States Department of Agriculture (USDA) (2015) https://www. aphis.usda.gov/biotechnology/downloads/reg_loi/15-078-02_ air_inquiry.pdf. Accessed 03 June 2020

United States Department of Agriculture (USDA) (2017) https://www. aphis.usda.gov/biotechnology/downloads/reg_loi/17-038-02_ air_inquiry_cbidel.pdf. Accessed 03 June 2020 
Van Acker R, Leplé JC, Aerts D, Storme V, Goeminne G, Ivens B, Légée F, Lapierre C, Piens C, Van Montagu MCE, Santoro N, Foster CE, Ralph J, Soetaert W, Pilate G, Boerjan W (2014) Improved saccharification and ethanol yield from field-grown transgenic poplar deficient in cinnamoyl-CoA reductase. PNAS 111:845-850. https://doi.org/10.1073/pnas.1321673111

Verma SR, Dwivedi UN (2014) Lignin genetic engineering for improvement of wood quality: applications in paper and textile industries, fodder and bioenergy production. South Afric J Bot 91:107-125. https://doi.org/10.1016/j.sajb.2014.01.002

Voelker SL, Lachenbruch B, Meinzer FC, Jourdes M, Ki C, Patten AM, Davin LB, Lewis NG, Tuskan GA, Gunter L, Decker SR, Selig MJ, Sykes R, Himmel ME, Kitin P, Shevchenko O, Strauss SH (2010) Antisense down-regulation of 4CL expression alters lignification, tree growth, and saccharification potential of field-grown poplar. Plant Physiol 154:874-886. https://doi. org/10.1104/pp.110.159269

Waltz E (2018) With a free pass, CRISPR-edited plants reach market in record time. Nat Biotechnol 36:6-7. https://doi.org/10.1038/ nbt0118-6b

Wan S, Li C, Ma X, Luo K (2017) PtrMYB57 contributes to the negative regulation of anthocyanin and proanthocyanidin biosynthesis in poplar. Plant Cell Rep 3:1263-1276. https://doi.org/10.1007/ s00299-017-2151-y

Wang P, Dudareva N, Morgan JA, Chapple C (2015) Genetic manipulation of lignocellulosic biomass for bioenergy. Curr Opin Chem Biol 29:32-39. https://doi.org/10.1016/j.cbpa.2015.08.006

Wang W, Pan Q, He F, Akhunova A, Chao S, Trick H, Akhunov E (2018) Transgenerational CRISPR-Cas9 activity facilitates multiplex gene editing in allopolyploid wheat. CRISPR J 1:65-74. https://doi.org/10.1089/crispr.2017.0010

Wang L, Ran L, Hou Y, Tian Q, Li C, Liu R, Fan D, Luo K (2017) The transcription factor MYB115 contributes to the regulation of proanthocyanidin biosynthesis and enhances fungal resistance in poplar. New Phytol 215:351-367. https://doi.org/10.1111/ nph.14569

Wang T, Wei JJ, Sabatini DM, Lander ES (2014) Genetic screens in human cells using the CRISPR-Cas9 system. Science 343:80-84. https://doi.org/10.1126/science.1246981

Wang HZ, Xue YX, Chen YJ, Li RF, Wei JH (2012) Lignin modification improves the biofuel production potential in transgenic Populus tomentosa. Indust Crops Prod 37:170-177. https://doi. org/10.1016/j.indcrop.2011.12.014

Welker CM, Balasubramanian VK, Petti C et al (2015) Engineering plant biomass lignin content and composition for biofuels and bioproducts. Energies 8:7654-7676. https://doi.org/10.3390/ en8087654

Wen S, Liu H, Li X, Chen X, Hong Y, Li H, Lu Q, Liang X (2018) TALEN-mediated targeted mutagenesis of fatty acid desaturase 2 (FAD2) in peanut (Arachis hypogaea $\mathrm{L}$.) promotes the accumulation of oleic acid. Plant Mol Biol 97:177-185. https://doi. org/10.1007/s11103-018-0731-z

Whitham SA, Qi M, Innes RW, Ma W, Lopes-Caitar V, Hewezi T (2016) Molecular soybean-pathogen interactions. Ann Rev Phytopathol 54:443-468. https://doi.org/10.1146/annurev-phyto $-080615-100156$

Win J, Chaparro-Garcia A, Belhaj K, Saunders DG, Yoshida K, Dong S, Schornack S, Zipfel C, Robatzek S, Hogenhout SA, Kamoun S (2012) Effector biology of plant associated organisms: concepts and perspectives. Cold Spring Harb Symp Quant Biol 77:235247. https://doi.org/10.1101/sqb.2012.77.015933

Xu C, Fu X, Liu R, Guo L, Ran L, Li C, Tian Q, Jiao B, Wang B, Luo K (2017) PtoMYB170 positively regulates lignin deposition during wood formation in poplar and confers drought tolerance in transgenic Arabidopsis. Tree Physiol 37:1713-1726. https://doi. org/10.1093/treephys/tpx093
Xu J, Hua K, Lang Z (2019) Genome editing for horticultural crop improvement. Horticult Res 6:113. https://doi.org/10.1038/s4143 8-019-0196-5

Xu R, Yang Y, Qin R, Li H, Qiu C, Wei LL, P, Yang J, (2016) Rapid improvement of grain weight via highly efficient CRISPR/Cas9mediated multiplex genome editing in rice. J Genet Genomics 43:529-532. https://doi.org/10.1016/j.jgg.2016.07.003

Xue L-J, Alabady MS, Mohebbi M, Tsai C-J (2015) Exploiting genome variation to improve next-generation sequencing data analysis and genome editing efficiency in Populus tremula $\mathrm{x}$ alba 7171B4. Tree Genet Genomics 11:82. https://doi.org/10.1007/s1129 5-015-0907-5

Xue L-J, Tsai C-J (2015) AGEseq: analysis of genome editing by sequencing. Mol Plant 8:1428-1430. https://doi.org/10.1016/j. molp.2015.1006.1001

Yang H, Zhang X, Luo H, Liu B, Shiga TM, Xi L, Kim JI, Rubinelli P, Overton JC, Subramanyam V, Cooper BR, Mo H, AbuOmar MM, Chapple C, Donohoe BS, Makowski L, Mosier NS, McCann MC, Carpita NC, Meilan R (2019) Overcoming cellulose recalcitrance in woody biomass for the lignin-first biorefinery. Biotechnol Biofuels 12:171. https://doi.org/10.1186/s1306 8-019-1503-y

Yang L, Zhao X, Ran L, Li C, Fan D, Luo K (2017) PtoMYB156 is involved in negative regulation of phenylpropanoid metabolism and secondary cell wall biosynthesis during wood formation in poplar. Sci Rep 7:41209. https://doi.org/10.1038/srep41209

Yoo CG, Dumitrache A, Muchero W, Natzke J, Akinosho H, Li M, Sykes RW, Brown SD, Davison B, Tuskan GA, Pu Y, Ragauskas AJ (2018) Significance of lignin S/G ratio in biomass recalcitrance of Populus trichocarpa variants for bioethanol production. ACS Sustain Chem Eng 6:2162-2168. https://doi.org/10.1021/ acssuschemeng.7b03586

Yu QH, Wang B, Li N, Tang Y, Yang S, Yang T, Xu J, Guo C, Yan P, Wang Q, Asmutola P (2017) CRISPR/Cas9-induced targeted mutagenesis and gene replacement to generate long-shelf life tomato lines. Sci Rep 7:11874. https://doi.org/10.1038/s4159 8-017-12262-1

Zambounis A, Ganopoulos I, Avramidou E, Aravanopoulos FA, Tsaftaris A, Madesis P (2016) Evidence of extensive positive selection acting on cherry (Prunus avium L.) resistance gene analogs (RGAs). Aust J Crop Sci 10:1324-1329. https://doi.org/10.21475 /ajcs.2016.10.09.p7825

Zeng Y, Zhao S, Yang S, Ding S-Y (2014) Lignin plays a negative role in the biochemical process for producing lignocellulosic biofuels. Curr Opin Biotechnol 27:38-45. https://doi.org/10.1016/j.copbi o.2013.09.008

Zhang Y, Bai Y, Wu G, Zou S, Chen Y, Gao C, Tang D (2017) Simultaneous modification of three homoeologs of TaEDR1 by genome editing enhances powdery mildew resistance in wheat. Plant $\mathbf{J}$ 91:714-724. https://doi.org/10.1111/tpj.13599

Zhang X, Dodds PN, Bernoux M (2017) What do we know about NOD-like receptors in plant immunity? Annu Rev Phytopathol 55:205-229. https://doi.org/10.1146/annurev-phyto-08051 6-035250

Zhang Y, Li D, Zhang D, Zhao X, Cao X, Dong L, Liu J, Chen K, Zhang H, Gao C, Wang D (2018) Analysis of the functions of $T a G W 2$ homoeologs in wheat grain weight and protein content traits. Plant J 94:857-866. https://doi.org/10.1111/tpj.13903

Zhang Y, Liang Z, Zong Y, Wang Y, Liu J, Chen K, Qiu JL, Gao $\mathrm{C}$ (2016) Efficient and transgene-free genome editing in wheat through transient expression of CRISPR/Cas9 DNA or RNA. Nat Commun 7:12617. https://doi.org/10.1038/ncomms12617

Zhang J, Zhang H, Botella JR, Zhu J (2018) Generation of new glutinous rice by CRISPR/Cas9-targeted mutagenesis of the Waxy gene in elite rice varieties. J Integr Plant Biol 60:369-375. https ://doi.org/10.1111/jipb.12620 
Zhao Q, Dixon RA (2014) Altering the cell wall and its impact on plant disease: from forage to bioenergy. Ann Rev Phytopathol 52:6991. https://doi.org/10.1146/annurev-phyto-082712-102237

Zhenga Q, Liua J, Goffa BM, Dinkins RD, Zhu H (2018) Genetic manipulation of miR156 for improvement of biomass production and forage quality in red clover. Crop Sci 56:1199-1205. https://doi.org/10.2135/cropsci2015.11.0726

Zhou X, Jacobs TB, Xue LJ, Harding SA, Tsai CJ (2015) Exploiting SNPs for biallelic CRISPR mutations in the outcrossing woody perennial Populus reveals 4-coumarate:CoA ligase specificity and redundancy. New Phytol 208:298-301. https://doi. org/10.1111/nph.13470
Zhu S, Yu X, Li Y, Sun Y, Zhu Q, Sun J (2018) Highly efficient targeted gene editing in upland cotton using the CRISPR/Cas9 system. Int J Mol Sci 19:3000. https://doi.org/10.3390/ijms19103000

Publisher's Note Springer Nature remains neutral with regard to jurisdictional claims in published maps and institutional affiliations. 